\title{
A PACIÊNCIA COMO TEXTURA DA ALMA
}

\author{
THE PATIENCE AS SOUL TEXTURE
}

\author{
Eduardo da Silveira Campos ${ }^{1}$
}

\begin{abstract}
RESUMO: No discurso de Kierkegaard sobre a paciência há uma correspondência entre a paciência e a alma adquirida. O exercício do pacientar é ele mesmo a alma sendo adquirida, de tal modo que, em algumas partes, ele nem mais fala em adquirir a alma, mas em adquirir a paciência. Dessa forma, poderíamos dizer que paciência é a textura temporal da alma, e a alma, por sua vez, a textura vital do tempo. Parece assim que somos capazes de tocar a própria alma, quando simplesmente acalentamos a vida que somos sob o sentido de um tempo extraordinário, que somente na paciência pode ser sentido. É em sua nudez que a alma despojada do mundo pode sentir a possibilidade de outro tempo.
\end{abstract}

Palavras-chave: Paciência; alma; mundo; nudez; vazio

ABSTRACT: In Kierkegaard's discourse on patience, there is a correspondence between patience and an acquired soul. The patient's exercise is the same as a soul being acquired, in such a way that, in some parts, he no longer talks about acquiring a soul, but about acquiring patience. In this way, we could say that patience is a temporal texture of the soul, and a soul, in its turn, a vital texture of time. It seems that we are able to touch the soul ourselves when we simply cherish the life that we are under the sense of an extraordinary time, which only in patience can be felt. It is in its nudity that the detached soul of the world can feel the possibility of another time.

Keywords: patience; soul; world; nudity; empty

\footnotetext{
${ }^{1}$ Doutor em Filosofia pela UFRJ. Pesquisador de Pós-Doutorado pelo Programa de Pós-Graduação em Filosofia (PPGF) do Instituto de Filosofia e Ciências Sociais (IFCS), da Universidade Federal do Rio de Janeiro (UFRJ). Pesquisador de Pós-doutorado pelo Programa de Pós-Graduação em Psicologia Social, da Universidade Estadual do Rio de Janeiro (UERJ). Pesquisador do Laboratório de Estudos e Pesquisas em Psicopatologia e Subjetividade do IPUB/UFRJ e Professor Colaborador do IFEN. E-mail: eduardodascampos@gmail.com.
} 
Não creio em nada senão na existência das minhas sensações; não tenho outra certeza, nem a do tal universo exterior que essas sensações me apresentam. Eu não vejo o universo exterior, eu não ouço o universo exterior, eu não palpo o universo exterior. Vejo as minhas impressões visuais; ouço as minhas impressões auditivas; palpo as minhas impressões tácteis. Não é com os olhos que vejo, mas com a alma; não é com os ouvidos que ouço, mas com a alma; não é com a pele que palpo, é com [a alma.] E, se me perguntarem o que é a alma, respondo que sou eu.(Álvaro de Campos).

Para estar disposto para o mais elevado, o coração deve assentar num puro nada, onde há também um máximo de possibilidade (Mestre Eckhart)

...esperar vale mais que entender... (João Guimarães Rosa)

Quando tocamos as coisas podemos sentir a textura de uma superfície lisa, rugosa, velosa, quente, fria. Mas não é apenas esse toque que as mãos humanas são capazes de fazer. Há toques que revelam uma profundidade vital mais originária. Essa origem que surge entre o tocante e o tocado é o instante de um toque que o filósofo francês Jean-Luc Nancy chamou de arquivida. Trata-se de um conceito que não fala sobre a "arquitetura do vivo", mas do próprio fulgor de uma "vida arquiteta" (NANCY, 2017, p. 65).Esse toque é a moção que encontra a vida de uma emoção, ou ainda, a sensação que encontra a sensação ${ }^{2}$ do outro. Essa emoção que a mão encontra sente a textura da afeição anímica da pele tocada; portanto, esse toque não é um mero tatear. Mas que toque é esse que nos faz ir ao encontro da vida, de sua arquivida? São muitos, mas todos singulares. É o toque consolador e aprazível no pelo do animal que quando chegamos do trabalho, nos recebe alegremente à porta de casa. É o que sente o pai curvado à cabeceira da cama, tocando a fronte do filho para velar seu medo em meio à noite escura. É o toque da mãe alisando a foto da amada filha já morta que o amor, contudo, não deixa morrer.

$\mathrm{O}$ primeiro toque que atinge a arquivida acolhe uma hospitalidade e doa carinho; o segundo acolhe um medo e doa guarida; o terceiro acolhe uma saudade

\footnotetext{
2 “... meus pensamentos são todos sensações” (PESSOA, 2016, p. 37)
} 
e doa esperança. Mas isso não significa que o pelo do animal ganha o sentido metafísico da hospitalidade; a fronte do filho, a metafísica do medo; a foto da filha, a metafísica da saudade. O toque toca, de fato, um pelo, uma fronte, uma foto, que não deixam de ter, para além da mediação de uma representação, uma decisiva imediatidade. Mas o toque acolhedor não capta apenas a parte de algo, mas a inteireza de uma presença, mediada apenas pela sensação do toque. Toca-se a existência.

Esses toques, portanto, não tocam uma superfície qualquer, meramente lisa ou fria, nem são os receptores sensitivos (os diversos "corpúsculos" da nossa pele) que estão aptos a captar, sentir, através de suas vias aferentes, esse sentido de mundo. Por detrás desses receptores corpusculares há um corpo, ou, como diz Zaratustra, um "poderoso soberano” (NIETZSCHE, 2011, p. 35). É esse corpo soberano que sente a profundidade vital da pele, exercendo no corpo do outro um toque capaz de sentir o que se segreda, a intimidade de um mundo que se abre retraindo-se. O gesto desse toque não desvela um determinado sentido que as coisas já trariam em si, como se pudesse revelar uma significação já definida e préexistente sobre realidade das coisas. Não. Na verdade, esse toque sente a abertura súbita de sentido que são as próprias coisas. As coisas não tem mundo, elas são mundo. Esse corpo tocante, entoado e animado pelo sentido do toque que toca, é o corpo da alma, a arquivida -psyché. O corpo da alma é o corpo como alma, o corpo que é alma tecida, pele anímica, sempre composta pela trama de um mundo.

O corpo da alma é, dessa maneira, um corpo dramático, quer dizer, um corpo que atua na situação, em uma determinada circunstância, lançado na cena do mundo, laçado pelos fios de sua trama ${ }^{3}$. Com esses fios se compõe a trama do drama de todo corpo anímico. E qual seria, afinal, a sua textura? O tecido desse

\footnotetext{
${ }^{3} \mathrm{O}$ corpo da alma tem a constituição do drama, cuja matéria pode ser tempo de desesperação ou de paciência. Quando em desesperação, esse drama logo se cansa. Mas, quando o tecido desse corpo anímico é por inteiro uma única fazenda, a inteireza de uma única ação necessária, ele está sendo feito/adquirido incansavelmente na paciência: "adquirir a sua alma na paciência inclina logo o espírito para a tranquila, mas incansável, acção” (KIERKEGAARD, 2007, p. 26).
} 
corpo possui a textura do tempo. Só a moção de um toque, em paciência, pode revelar a arquivida, encontrando o tempo extraordinário em que a vida se afeiçoa, se comove.

Apesar de pouco frequente, é por meio do corpo anímico que o humano toca as coisas. Ele toca essa superfície profunda da vida que, na verdade, só existe mesmo enquanto superfície, no aparecer de um mundo, na circunstância que o enlaça e o aperta, na dinâmica da própria vida enquanto drama consigo mesmo e com os outros. O toque no pelo do animal, o toque na fronte do filho, o toque na foto da filha que se foi, trazem à luz instantes de drama, de corpos dramáticos, i.e., da vida enquanto ação, lida, história. Uma história que não é o mero registro de fatos do passado, mas de uma história por vir, de uma vida que é, ao mesmo tempo, saudade, paciência e esperança, pois a vida é a trama de uma encruzilhada de tempos. É o que diz João Guimarães Rosa: "Tudo que já foi, é o começo do que vai vir, toda a hora a gente está num cômpito" (ROSA, 2006, p. 312).

É saudade enquanto amor pelo que foi - tempo passado; esperança enquanto amor pelo que será- o tempo futuro; paciência enquanto amor diante do que é e está sendo - tempo presente. Mas a paciência não é o mero esforço de suportar o tempo que nos separa de um bem que almejamos, como acontece durante a espera que nos faz suportar o desejo de adquirir o bem da saudade ou o bem da esperança. A paciência é o amor diante do que é, mediante o que foi e será. Mas o que é que se guarda na presença desse é que a paciência ama e quer tocar, adquirir, mas que não é nem o bem da saudade nem o bem da esperança?

Esse é que já é, e que a cada vez vem a ser, é o entre, a passagem do tempo entre aquilo que foi e aquilo que será; é o que a cada vez se sucede como drama. Este é o modo de ser da própria vida, da alma, ou ainda, da alma situada, encruzilhada, encorpada na e pela ação. Por essa razão, a constituição da alma, da vida, é drama. Passado, presente e futuro são os fios dessa trama; e a saudade, a paciência e a esperança são as paixões que cuidam desses fios, porque são elas, como Graças 
abraçadas, esses próprios fios. Mas, de todas essas, a paciência é a que possui a força do maior desvelo, porque é ela que nos guarda na saudade e nos guarda na esperança. Ela nos guarda para que não percamos a vida no é do presente dramático que está sempre sendo visitado pelo desejo do que foi e pelo desejo do que será. E ela só pode fazer isso, porque seu objeto de amor não é o mesmo bem da saudade nem o bem da esperança. Sendo assim nos cabe fazer uma pergunta: qual seria o bem da paciência, o que ela pode querer adquirir? Se a saudade toca a ausência do que foi, e a esperança toca ausência do que será, o que toca a paciência na presença do que é e está sendo, mas que, apesar de presente, se ausenta, escapa, mostrando-se, por isso, como aquilo que precisa ser adquirido? Para Kierkegaard, a única coisa necessária que precisa ser adquirida é a própria alma. Saudade e esperança são os fios que constituem o seu drama, e a vida, quando saudosa do bem passado ou esperançosa do bem futuro, pode ter sua trama tecida em desesperação. Mas a alma, quando adquirida, é tecida com os fios da paciência.

Mas onde se situa a alma para que possa ser adquirida? Por ser drama, a alma não é uma entidade que está localizada em uma determinada região do corpo (no cérebro, no córtex nem mesmo na glândula pineal, como conjecturou Descartes), mas ela é a própria lida da existência que faz com que o corpo, no combate de cada luta,seja a alma dramática que é. Por essa razão, podemos tocar a alma do outro e a nossa, porque no toque tocamos a superfície de uma trama extraordinária, tecida com os fios que enredam a história que somos com nós mesmos e com os outros.

Acabamos de dizer uma coisa estranha: podemos tocar a superfície da trama anímica que somos nós mesmos in acto. Dissemos que não apenas podemos tocar a trama existencial alheia, i.e., a vida, o corpo da alma alheia. Podemos também tocar, e tocar decisivamente, o nosso próprio tecido anímico que também se move na pele de um drama. Mas como podemos acessar a nós mesmos com um toque? É possível? Resposta: sim, é possível. Mas como? Apenas se esse toque não for feito, evidentemente, com os olhos reflexivos da autoconsciência que, revirados sobre si 
mesmos, apenas pode refletir sobre a própria vida. No máximo que essa consciência de si pode fazer é tocar-se em desespero a partir da busca inglória de um autoconhecimento ${ }^{4}$, do conhecimento que passa a ter de si própria, do próprio eu dramático, quando se depara com aquilo que se é mas que, não obstante, não quer ser. Eis a fórmula do desespero!

Mas Kierkegaard diz que há uma maneira especial de tocar a si, de tocar-se, que não apenas toca como um mero conhecer a si mesmo, como quem toma consciência da textura do próprio drama. Esse contato especial, que pode tocar radical e extraordinariamente a vida, acalenta, acalma, pacienta a própria vida. Assim, na paciência ${ }^{5}$, tocamos sutilmente a alma, o drama que somos. E o tocar aqui precisa ser visto, entrevisto, não apenas com o sentido de um toque que possui o mero tatear. Não. O toque que a paciência exerce toca não apenas o sentido trivial da textura de algo, mas toca a vida como quem toca entoando música (ou seja, criando) ou como quem toca conduzindo um rebanho (ou seja, guardando) ou como quem toca acalmando o filho (ou seja, serenando). Dessa maneira, a paciência é um toque que pode aferir o mundo que a fere, afeiçoando-se consigo mesma, a despeito da insistência do mundo, entoando-se em sua toada, tocando meditativamente a própria alma e, com o mesmo gesto, tocando a própria vida que criativamente se conduz, levando-se na cadência de um outro andamento vital. Sendo ferida, a paciência afere a própria vida e desfere, no mundo e contra o mundo, seu golpe criador. Nesse ato criador, a alma adquirida move a si mesma, desde si mesma, e não mais a partir do mundo constituído. Na resistência dessa tensão ferida, ela cria seu próprio tempo de ser no mundo. Ora, a dor, em si, não é o que mais dói na dor; o que mais dói no doer da dor é o tempo que leva o seu padecer. E desespero e paciência são paixões que criam o tempo da dor. O desespero, que vive na temporalidade, alonga o tempo; a paciência, que espera uma eternidade, encurta o tempo. A paciência é quem serena a dolência do tempo.

\footnotetext{
${ }^{4}$ Kierkegaard, 2007, p. 32.

${ }^{5}$ A tradição chamou essa paciência também de "meditação", "oração".
} 
Para Kierkegaard, a vida, através dos serenos dedos da paciência, toca a profundidade do próprio existir e, como dramaturga, reescreve a cada vezo próprio ensaio, experienciando-se sob um novo instante, sob um novo ritmo, sob uma nova atmosfera dramatúrgica. A vida recolhe-se pacientemente em si para tocar-se, adquirindo a cada vez uma medida que recria a escritura do próprio drama. Mas como seria, afinal, esse recolhimento da alma adquirida na paciência? A resposta sobre esse como é simples: adquire-se na paciência. E o que significa esse na paciência? Significa que não é por meio dela, pela paciência, como se ela fosse o caminho para outra coisa, o meio que visa um fim desejado. Mas se não é pela paciência, e sim na paciência, precisamos então explicitar a dinâmica desse na(em dinamarquês $i$ ) paciência, querendo adquirir uma alma que parece estar lá.

Em sua ação, a paciência não almeja a exterioridade, que Kierkegaard chama de "mundo" . Portanto, ela jamais é meio para um fim exterior, para conseguir alguma coisa que está fora. A paciência repousa em si absoluta, aquiescendo em si mesma, recolhendo-se na própria interioridade da ação, no próprio desempenho de ser pacientemente o drama que se é: sua necessidade vital. $\mathrm{Na}$ paciência não há, portanto, almejar, mas o almar da alma almando-se, amando-se, adquirindo-se a si mesma segundo o verbo de um determinado drama. Esse almar é o gesto de aguardar sem a expectação do bem desejado (atitude que Heidegger chamou de serenidade). Ou seja, o na onde a alma guarda-se, na paciência, é ele mesmo o lá que se quer adquirir. O na paciência é própria alma a cada vez sendo adquirida. $A$ paciência é ela mesma a textura que a alma toca quando se toca adquirindo-se. É a moção dramática que se comove na espera da paciência. Essa imbricação circular entre alma e paciência está explícita na seguinte passagem: "A expressão não diz pela ou mediante a paciência, mas 'na' paciência e sugere, por este meio, que a condição se encontra numa relação especial com o condicionado" (pp. 22-23).

\footnotetext{
${ }^{6}$ KIERKEGAARD, 2007, p. 17.
} 
Essa calma que serena na pobreza da solidão do drama é o que está dizendo a frase que intitula o discurso edificante de Kierkegaard: Adquirir a sua alma na paciência.O na é uma espécie de canto da vida, canto do tempo, onde o drama, por um instante, para, repousa, recolhendo-se em si mesmo, inteiriçando-se, concentrando-se na tensão de uma essencial espera. Esse recanto da vida, que espera apenas adquirir a si mesma e mais nada, é o instante no "qual a alma, na paciência, se encasula, e assim adquire quer a paciência, quer a si mesma"7 (KIERKEGAARD, 2007, p. 28). Esse encasulamento da alma na paciência é o lugar, o canto de uma guarida, o encontro com o próprio ethos, a gênese de toda ética, a arquivida de toda relação, onde a alma pode ser, estar, existir, suspensa em um instante crisálido que medita, à medida que se transfigurana ação.

Em dinamarquês, a expressão reflexiva "se encasula" é spindersig, que diz "fiar-se", "tecer-se", ou melhor ainda, "fiar em torno de si", "tecer em torno de si", como faz a lagarta ao tecer pacientemente a textura que guarda,na paciência, a possibilidade da própria transformação, da metanoia. A alma, na paciência, tece em torno de si uma guarida, uma morada, uma casa. Com os fios da paciência, quer dizer, pacientemente, a alma edifica para si própria uma casa, um ethos possível. Poderíamos então dizer, a partir de Jean-Luc Nancy, que a paciência é a paixão da arquivida arquitetando, edificando o próprio ethos; sendo, assim, a paciência é princípio para a composição de qualquer ética.

Essa casa edificada sob o engenho da paciência é o que dá medida à vida, é o que dá à alma um canto, um ethos. Esse é o instante em que a almas e resguarda e, embalada pelo mesmo gesto, transforma-se, transmuta-se. É dessa forma que, na paciência, a alma torna-se leve, livre, lépida, alciônica: borboleta-se. O gesto de resguardar-se é o mesmo gesto que gesta o salto transfigurador da "repetição"(KIERKEGAARD, 2013, p. 23).Adquirindo-se a si própria, ela pode tecer-se, guardando-se na duração do drama anímico, tramando a própria vida na

\footnotetext{
7 “...i hvilken Sjelen i Taalmodighed spinder sig indogderveder hver verdenog sig selv” (sks, 170, 79).
} 
urdidura paciente da $f e$, para assim deixar de ser o desespero que não consegue destecer-se para morte, não consegue ser desde a finitude do próprio caminho.

O acalanto do ethos da paciência acalma a alma da fissura do "mundo" ${ }^{\text {. A }}$ alma fixada no "mundo", atendendo ao seu insistente apelo de ter de ser o que não é, está esquecida da dramática possibilidade de ser o que propriamente se é. A paciência nos guarda desse afã, da sanha, do desejo incontrolável de ter de ser uma miríade de possibilidades que nos toma na faina diária do drama. Mas ela, a paciência, não apenas nos mostra que não precisamos ser a moral do "mundo", mas nos educa para sermos o que, de alguma forma, já somos, ou seja, educa-nos para a possibilidade de ser apenas a necessidade que somos. A paciência nos ensina a querer tocar a intimidade do que já somos, para sermos na solidão de uma tarefa inalienável. Na paciência adquire-se a evidência, a sabedoria, a experiência de já ser o que precisamos almejar ser, almar. A evidência de já sermos essa possibilidade que somos não nos deixa perdidos no desespero de ser o que não somos.

Mas todo desejo incontrolável, a fissura pelo" mundo", está cego para o drama que se é, porque, nessa fissura, o "mundo" acaba sendo a instância de ruptura com o que somos; e é justamente aqui, com essa ruptura, que começa o "desespero de não querermos ser nós próprios" (KIERKEGAARD, 1979, p. 195).Esse desejo incontrolável de ter de ser o que não se é, e que não possui a saúde de um decisivo abandono (forlade), vivencia o drama que Pessoa identifica na lida do poeta:

Não sei quantas almas tenho.

Cada momento mudei.

Continuamente me estranho.

Nunca me vi nem achei.

De tanto ser, só tenho alma.

\footnotetext{
8 A partir de agora, sempre que a palavra "mundo" estiver posta entre aspas será tão somente para destacar o sentido de "mundo" do contexto do discurso edificante de Kierkegaard sobre a paciência, e não mais apenas com aquele sentido ser em uma situação, circunstância, como descrito acima; agora, o drama de ser em uma situação (mundo) está atrelado ao "mundo” já constituído, cristalizado como coisa pelo desejo da alma ambiciosa, aderida a um “mundo” do qual só pode desprender-se na paciência.
} 
Quem tem alma não tem calma9 .

De fato, a princípio, "quem tem alma não tem calma", porque sempre temos a alma como aquilo que precisa ser adquirido na paciência, pois sempre temos a alma como tarefa. Imediatamente, estamos lançados no desespero de ser ou não ser o que somos, e, por isso, Pessoa afirma que "Quem tem alma" - diria Kierkegaard, quem apenas possui a alma ${ }^{10}$ - "não tem calma", porque apenas a possui como aquilo que precisa ser adquirido, acalmado na paciência. Mas Alberto Caeiro, mestre grego de Álvaro de Campos e Pessoa, fez essa experiência de aquisição da alma, pois em sua voz não tocamos o drama de qualquer desesperação:

Sejamos simples e calmos,

Como os regatos e as árvores,

E Deus amar-nos-á fazendo de nós

Belos como as árvores e os regatos,

E dar-nos-á verdor na sua primavera,

E um rio aonde ir ter quando acabemos!...

(PESSOA, 1986, p. 208)

$\mathrm{Na}$ paciência somos envolvidos no ethos que possibilita tocar a vida do outro e a nossa própria vida, entoando-nos nelas e por elas. $\mathrm{Na}$ paciência não fazemos mais um toque ligeiro, descomprometido, porque tocamos demoradamente para sentir um novo mundo desvelando-se. $\mathrm{Na}$ paciência sentimos mais que o pelo do animal, sentimos a sua hospitalidade; mais que o suor da fronte do filho, sentimos o seu medo; mais que a película do retrato filha, sentimos a sua pele viva. $\mathrm{Na}$ paciência também tocamos a textura da própria alma, a textura do drama que somos, que se compõe com os fios tecidos no próprio pacientar; tocamos assim com lira e cajado, i.e., entoados e conduzidos para desejar ser o que realmente somos. $N a$ paciência tocamos a "nudez, último véu da alma" (DRUMMOND, 2015,p. 14). Na paciência tocamos o instante da arquivida.

\footnotetext{
${ }^{9}$ http://arquivopessoa.net/textos/277
}

${ }^{10}$ KIERKEGAARD, 2007, pp. 16-17 


\section{Pacientar-se no mundo}

Até aqui vimos que a espera da paciência está na base de qualquer hermenêutica e de qualquer ética, porque ela zela, desde as camadas mais profundas da vida, pela arquivida, zelando as disposições anímicas com as quais sentimos/tocamos o mundo antes de qualquer reflexão, elaboração. O labor da paciência age antes de qualquer elaboração mais reflexiva. Ela mostra-se assim não como um meio para um fim, mas como o próprio meio adquirindo-se a si mesmo, ou seja, o próprio médium que inclui o fim. De tal maneira que Kierkegaard chega a falar no texto nem mais sobre o labor em torno da aquisição da alma, mas sobre a aquisição da própria paciência ${ }^{11}$.

Alheado da existência, o desinteresse do senso comum pensa apenas a partir de pressupostos imediatamente dados e, por isso, costuma posicionar a paciência como um meio, um instrumento, para alcançar um fim. Obviamente, ele até pode considerar que o fim seja a alma, contudo, o senso comum entrevê, na transparência da alma, aquilo que não é propriamente a alma, e sim o que ela deseja: o almejado. $\mathrm{O}$ almejado está aderido à alma, e adquirir a alma na paciência, nesse caso, seria também supor a aquisição do almejado; e a paciência, apenas um meio para esse fim. Assim, a paciência é compreendida apenas como um caminho pelo qual se adquire o desejado, o almejado. Mas, no discurso edificante de Kierkegaard, a paciência não é o caminho para/do desejo, mas para a própria alma, ou melhor, o exercício da paciência já é, ele mesmo, a alma sendo adquirida, amando-se, almando-se. A alma possui a mesma textura temporal da paciência, e a paciência a mesma textura vital da alma.

Há uma circularidade e imbricação entre a travessia da alma e a travessia que a paciência perfaz com ânimo. Para ambas, a distância e o andamento é o mesmo. A paciência é o começo, o meio e o fim de toda a travessia do almar, e a alma é o começo, o meio e o fim de toda a travessia do pacientar. Para que isso seja possível,

11 “... pois só quando quer adquirir a paciência, só então não se torna devedor de ninguém” (p. 24). 
para que a circularidade da paciência não perca a contiguidade com a circularidade da alma, para que a paciência não se transforme simplesmente em algo que tenha antecedência cronológica, como uma espécie de instrumento prévio que serve apenas para acessara alma, é preciso que a alma adquirida veja e seja tão somente o ensejo da transparência do nada, que, nas palavras de Kierkegaard, é a "nudez da alma" (KIERKEGAARD, 2007, p. 16).

É dessa forma que Kierkegaard concebe a paciência quando diz que ela é semelhante a um "pássaro pobre" (p. 9), porque ela nada tem e nada é, ou um nada que é apenas possibilidade de ser. A alma nua é a alma desprovida de qualquer coisa, cingida de abandono por dentro e por fora. Na transparência da alma adquirida não se vê a sombra de qualquer almejado. Significa então que a alma não mais almeja, não mais deseja? De forma alguma. No entanto, a alma pacientada não é mais um querer sôfrego e ansioso que busca, mas um querer que calmamente acolhe. Seu querer é um acolher, pois é um querer que coincide sempre com o possível. Esse casamento perfeito entre poder e querer forja a santidade da vida de Nhinhinha, em A menina de lá de J. G. Rosa, ou mesmo a cariz grega de Ricardo Reis, estendendo grato seu balde vazio para acolher a chuva que dentro dele cai: "Meu balde exponho à chuva, por ter água./Minha vontade, assim, ao mundo exponho./Recebo o que me é dado,/E o que falta não quero (PESSOA, 2016, p. 138).

O desejo do almejo é a fixação avara da alma em algo que turva sua constitutiva transparência, privando-a assim de apenas ser o cristalino de um ver capaz de contemplar a vida em seu constante statu nascendi. Para ser esse captar de vida, a alma precisa ser apenas o "sonho da passagem"(PESSOA, 1986, p. 173), como diz Álvaro de Campos. Ser passagem é ser a travessia da poética do olhar: “...a nossa única riqueza é ver”(p. 208). Isso que turva, macula a transparência do olhar da alma, deixando-a retida e encegueirada por algo, Kierkegaard chama de "mundo"; e a libertação desse "mundo", o seu abandono, é o esforço de um deixar. 
Esse deixamento que se dá na paciência adquire a alma pari passu ao desprendimentodo "mundo". O desprendimento libera o nada de onde sempre irrompe possibilidade: o ânimo da alma, a sua vida animada diante do possível. $\mathrm{Na}$ paciência aprende-se, não a almejar, mas a almar. A paciência é o almar enquanto ação de desprendimento da alma. $\mathrm{Na}$ paciência se exerce a transcendência que deixa a alma saltar, ultrapassando o "mundo", seu estado de coisas. É isso que diz o verso da conhecida música popular brasileira: "Alma vai além de tudo que o nosso mundo ousa perceber. Casa cheia de coragem [paciência!], Vida, tira a mancha que há no meu ser. Te quero ver, te quero ser: alma" -almar. Mas de que maneira alguém poderia perder sua alma na impaciência através da lida com o "mundo"? Vejamos isso ilustrado na vida de uma certa mulher.

Sua casa tem uma rotina, e ela é divorciada. Seus filhos estão diuturnamente sob seus cuidados. Além disso, ela trabalha em casa e trabalha fora. Ela está no trabalho e, ao mesmo tempo, está trabalhando em outros ambientes, a despeito de não estar neles fisicamente presente. Ela está no colégio; ela está em casa; ela está na casa do marido que se foi; ela está na fila do banco, etc. Seu corpo tem esse poder de conectar-se simultaneamente a vários lugares, e cada lugar desses possui a sua alma. Ela está completamente assoberbada, atravessada por inquietações, a ponto de enlouquecer por tamanha pressão que a oprime e comprime na angústia da liberdade. E é precisamente nesse ínterim de sofrimento, no auge de um dilaceramento vital, que uma menina, bem mais nova e solteira do seu ambiente de trabalho, refestelando-se, vira-se languidamente para ela, dizendo: "Tenha paciência!". A palavra da menina - que não tinha noção do que é a paciência enquanto textura temporal da alma adquirida - não apenas não lhe soou bem, como também lhe provocara uma profunda inquietação existencial. Contudo, à noite, quando todos já estavam em suas camas, uma angústia ainda a visitava através da palavra da moça do trabalho, ressoando como um zumbido incômodo, repetitivo e alucinante: “Tenha paciência! Tenha paciência!...”. Essa voz varou sua 
madrugada insone, mas o efeito daquela frase inoportuna, ao fim e ao cabo, já não era mais o da inquietação e o da revolta - aconteceu uma reviravolta. O apelo irritante da moça lhe atingira decisivamente, a despeito do seu tom professoral, leviano, inadvertido. A paciência, que antes era o que devia "ter" para poder fazer tudo o que precisava fazer, agora era aquilo que a possuí, comedindo diuturnamente o que dela era exigido. Que seria esse comedimento na paciência? Comedir é trazer para uma medida, para o médium do interesse essencial da própria vida.

Em sua angústia algo se decidir a: a partir de agora tudo seria medido, co-medido pela própria vida, e não mais a sua vida seria medida e co-medida pelo tudo. A partir daí, somente partir da medida da própria vida (alma), é que uma nova possibilidade poderia surgir, dando-lhe novos rumos, bem como a possibilidade de poder morrer por esses rumos, "estiolar-se" ${ }^{12}$ (afdøe), curando-se, assim, do desespero. A angústia é o instante decisivo em que se abre uma nova possibilidade ser, criar. O "mundo", para Kierkegaard, é uma medida posta de fora que deseja co-medir a vida a partir de uma medida que não é a doada pelo andamento lento, certo e preciso da paciência. É apenas a paciência que pode mensurar, que pode dar medida ao andamento da alma. Adquirida na paciência, a alma pode criar novas possibilidades de ser, existindo na solidão da interioridade do próprio ethos. A paciência temporaliza a vida segundo o tempo do eterno.

$\mathrm{Na}$ paciência conquista-se a medida que co-mede a vida conforme a nudez constitutiva da alma. Mas esse nada que se descobre na nudez não é os escombros do niilismo de nada sobre nada. Não. Seu nada é um nada criador, o nada desde o qual pode sempre irromper possibilidade. "Adquirir a alma na paciência" é justamente o exercício de uma tensão vital que ajusta o nó entre nada e possibilidade. Sobre a alma daquela mulher parece que soprara de repente aquele mesmo vento sereno que soprou e pacientou a alma de Cecília Meireles: "O vento do meu

\footnotetext{
${ }^{12}$ Sks, $11,118$.
} 
espírito soprou sobre a vida./E tudo que era efêmero/se desfez/.E ficaste só tu, que és eterno..." (MEIRELES, 2001, p. 121).

Que sopro é esse que serena a alma, desfazendo o que se desfaz - o "efêmero"? É o sopro ${ }^{13}$ decisivo do instante. Esse sopro é o frescor de uma linguagem que nos sobrevém como ânimo, suspendendo-nos em um instante de paragem que desfaz a passagem, o efêmero. Essa respiração serena é uma oração, uma meditação, que vive o sossegado instante da abolição sucessiva do tempo, o eterno. Mas não somente isso: ela é uma oração que é ação e uma ação que é oração. Portanto, é, ao mesmo tempo, uma oração atuante e uma ação orante. Não se trata de uma coisa e depois outra, conseguinte a outra, mas um acontecimento que faz com que o orar dessa linguagem seja, ao mesmo tempo, ação, e o fazer dessa ação seja também, ao mesmo tempo, oração. Uma máxima antiga diz: Ora et labora. Esse et do latim não é disjuntivo, mas conjuntivo, integrativo. Ele ajusta um orar laborante a um labor orante. Eles estão integrados como o mais originário gesto criador da linguagem. Quem faz a separação disso é o pensamento objetivo. A existência não separa aquilo que já é sempre junto, imbricado, atado como o nó da vida.

A palavra dinamarquesa Taalmodighead, que costuma ser traduzida como paciência, é a junção do verbo at taale, que significa "aguentar, suportar, suster" mais modig, que possui o sentido de "coragem, ânimo". Paciência é, portanto, agüentar corajosamente, com ânimo, a tensão de um nó vital. O aguentar não é sustentar um nó que deseja prender, controlar, mas é a grande tensão de um desenlace que pode deixar ser. Isto é, na tensão da paciência aguenta-se um deixar ser, acontecer. Com essa tensão mantida, a paciência guarda a alma da lassidão, logo, da capitulação pelo "mundo". Na paixão da paciência todo esforço concentra-se em abandonar o "mundo", não em abandonar-se nele. Abandonar o "mundo" não é fugir do "mundo", mas estar nele sem ser dele. A desapropriação do "mundo" é o mesmo gesto da apropriação de si, da própria alma. E é do vazio da desapropriação que

${ }^{13}$ Cf. O Sopro do eterno: sobre verdade, vida e amor em S. A. Kierkegaard/Ramon Bolivar Cavalcanti Germano. João Pessoa, 2018. 204 f.: il. 
pode eclodir o ser da apropriação. Nesse mesmo espírito, em O Arco e a lira, Octavio Paz falado labor da oração, i.e., da meditação do pensar: "Pensar é respirar, reter o alento, deter a circulação da ideia: produzir um vazio para que o ser aflore" (PAZ, 1982, p. 126). Esse vazio, que perfaz o "sonho da passagem", é a alma. O pacientar dessubstancia a alma, descoisifica a alma, como quem a despe para poder assim tornar-se a nudez do verbo almar - o verbo que pode realizar com calma e liberdade as ações de quaisquer verbos.

\section{Pacientar-se contra a paciência do mundo}

No discurso da paciência, Kierkegaard apresenta o sentido do pacientar, à medida que coloca em questão o conceito de paciência que grassa no dia a dia. Em determinados momentos, através do lirismo encantador de sua escrita, ele atrai intencionalmente o leitor para acreditar na ilusão daquele sentido imediato que todos possuem, a saber, a paciência como meio para se chegar a um fim desejado. O texto nos seduz intencionalmente para isso, afirmando provisoriamente essa mesma tendência natural, segundo a qual a paciência é aquela "força da alma necessária a cada homem para alcançar aquilo que deseja" (KIERKEGAARD, 2007, p. 11).Mas tudo isso é apenas um engodo estilístico que nos encaminha para a verdade da paciência.

Esse entendimento que ele apresenta sobre a paciência é razoável, e o texto, por estratégia, reforça-o, brinca com essa plausibilidade, agravando, por alguns instantes, essa tendência ilusória do leitor. A bela forma como Kierkegaard expõe essa tendência se mostra como um discurso de conforto, porque diz que se tivermos paciência alcançaremos o que desejamos. Contudo, todo esse lirismo que seduz a alma leitora é apenas um engodo que acintosamente mantém a consciência enlevada, preparando-a para o golpe derradeiro que anuviará aquele clima agradável e consolador que fora aberto por palavras de incentivo, que reforçaram, no leitor, a crença de que a paciência é apenas um meio para alguma coisa final. 
Obviamente, tratar-se-ia de uma defesa razoável, e qualquer pessoa de bom senso tenderia a confirmar tais palavras. Mas, subitamente, como quem provoca a queda dos que foram entorpecidos pelas palavras de ânimo, Kierkegaard trespassa de forma lancinante a alma do leitor, acostumado ao sentido comum da paciência, dizendo que esse caminho que descrevera, por mais razoável e agradável que ele seja, apenas corrobora a desesperação da alma. O sentido construído pelo senso comum faz com que a paciência seja tão somente um meio para alcançar o desejado, sendo a impaciência justamente aquilo que colocaria tudo a perder. Esse modo de ser segundo o sentido da paciência do senso comum, que tem a paciência apenas como meio para um determinado fim almejado, condiz com a alma em estado de latente desesperação, maximamente perdida sob a posse do "mundo".

Esse estilo tipicamente kierkegaardiano lança a alma do leitor na confusão de um torvelinho hermenêutico que favorecerá a abertura para o sentido mais radical do pacientar, para aquele que é objeto de todo o texto. Vejamos uma das passagens em que Kierkegaard afunda o leitor nesse estado de enlevo e ilusório. Ele diz: "...que a mãe que quer obter alegrias com o seu filho não deseje que ele cresça depressa, mas espere pacientemente em noites de insônia e dias inquietos." (p. 12). A ternura da figura da mãe com o filho, e a recomendação para aquietar o seu desejo, são palavras que trazem um pressuposto inatacável, qual seja: a mãe precisa ter paciência e aquietar-se, deixando que seu filho cresça sem pressa. A verdade de tais palavras emoldura a frase, tornando-a um truísmo difícil de ser derrubado. Contudo, contra essa tendência, Kierkegaard encerra essa longa passagem, que apresenta a paciência como um meio para, dizendo: "A condição de que se fala é exterior ao homem e a condição para por meio disso, alcançar aquilo que deseja é a paciência, de sorte que ele não conquista propriamente a paciência, mas sim o desejado" (p. 13). A beleza do truísmo, que Kierkegaard propositadamente faz florescer, como um receptáculo para as nossas ânsias desejantes, despetala-se subitamente, deixando ser apenas a vaziez sem pétalas de um cálice floral, aguardando a possibilidade de um novo florescer. Mas o vazio desse cálice é 
justamente o princípio e o fim da alma adquirida na paciência. Kierkegaard entra no engano da ilusão e, subitamente, desengana o engano desde dentro, que como uma flor, diante de uma súbita ventania, despetala-se para ser na nudez da alma. Este instante inopinado é o duro golpe que o pensador desfere contra o pressuposto do senso comum (a paciência como um meio para), por mais belas e aprazíveis que sejam as suas intenções, e nobres os seus desejos.

Após levar o leitor ao entorpecimento da ilusão, descrevendo a paciência como aquele instrumento que serve ao desejo, Kierkegaard desfere a estocada final que fere a alma para que possa ser apenas o desamparado essencial da nudez da alma. Ele fala sobre esse novo "caminho", dizendo:

Caminho onde, por assim dizer, nunca se adquire nada: nem alcançar a meta, nem descarregar o fardo, nem a rica colheita, nem a riqueza, nem a magnífica captura, nem a felicidade do filho, nem o favor dos homens, nem o ter aproveitado a outros - mas antes se adquire apenas a si mesmo (uma recompensa que é tão pobre que mesmo a criancinha que morre no instante do nascimento aparentemente a possui) (p. 14).

A passagem é implacável, incontornável. Apresenta a paciência não como um meio para atingir a meta ambicionada, mas como sendo a própria meta que se concretiza a partir da experiência que consiste em ter a vida pacientemente nomeio, ou melhor, a meta acontecendo como o próprio exercício do meio. Essa não disjunção entre o meio (a paciência) e o fim (a alma) mostra-se como uma injunção vital que impõe um liame constitutivo entre paciência e alma, de tal maneira que a paciência se mostra como a textura temporal da alma, e a alma como textura vital da paciência. A constituição da alma é tempo. Por isso, a paciência pode eternamente esperar, porque ela não precisa chegar para chegar, pois sempre chega na sempiternidade do aguardo da paciência.

Esse caminho que a paciência perfaz, afirmando o próprio percurso do meio, faz com que o mais palpável e seguro da exterioridade se apresente como o mais 
inseguro; e aquilo que era o mais frágil, invisível, transforme-se no espírito de uma experiência inabalável. Através de uma interrogação, ele afirma isso:

“...não será semelhante revolução no pensamento e na linguagem algo mais estranho do que o mais estranho -que a vida se transforme de tal modo para o homem que aquilo que é tangível, aquilo que para ele era o mais certo de tudo, se torne duvidoso, e o espiritual, que o enganava pela sua distância, se torne o mais certo, infinitamente mais certo do que o tangível?" (p. 15).

Apesar do deslocamento vital que essa jogada argumentativa de Kierkegaard provoca no leitor arredio, é comum, ainda assim, tomarmos esse espiritual que se apresenta na paciência como "o mais certo", com o sentido tipicamente assumido pelo senso comum religioso, pois, nesse caso, a paciência apresenta-se como condição necessária para se adquirir, oportunamente, as benesses que "Deus" poderá conceder. Esse pode ser o caso das religiões que afirmam o espiritual enquanto coisa "sobrenatural", agindo com certos poderes que orientam a vida dos humanos. Mesmo no caso do ateu asceta que deixou tudo e foi para a floresta, porque entendeu que não possuir qualquer bem material seria imediatamente adquirir a alma, para ele, igualmente, a paciência pode ser relegada à condição instrumental. Esse eremita sem fé pode estar carregando consigo o "mundo" para o interior da floresta. Para além de qualquer situação de isolamento, é a paciência é coração da verdadeira solidão. Portanto, nem a lógica religiosa nem a ascese da ermitania ateia condizem necessariamente com uma alma adquirida na paciência.

\section{Pacientar-se como desnudar-se e esvaziar-se}

O decisivo na paciência é sentir e consentir o desprovimento da "nudez da alma". Por essa razão, esse modo de ser alma, ainda que perca tudo, não sente perder nada, porque sabe que nada possui. Essa alma também não deseja nada de impossível, porque sabe que possui todo o possível e necessário. O perigo dessas afirmações que acabamos de fazer é o risco de, mais uma vez, serem compreendidas a partir do senso comum religioso, que pode conceber esse 
movimento de aquisição da alma, como sendo um simples movimento ascético de resignação. Mas esse movimento da alma, na paciência, não é somente um movimento de resignação, mas o movimento da fé, ou a fé como o próprio movimento de desprendimento do pacientar-se. Cecília Meireles viu a possibilidade da experiência de um abandono sem tristezas, apelando para que a alma se guarde de ser uma consciência que observa com lamento o ato de deixar.

Sê o que renuncia

Altamente,

Sem tristeza da tua renuncia

Sem orgulho da tua renuncia

Abre a tua alma sobre a tuas mãos,

Abre tuas mãos sobre o infinito

E não deixes sobrar de ti

Nem esse último gesto.

(MEIRELES, 2001, p. 134)

"Não deixes sobrar de ti/Nem esse último gesto". Desse último "gesto", a consciência pode tomar ciência, amargurando-se com a sua renúncia. Essa consciência que tem ciência do deixar, pois vê que se trata de um abandono, olha para tal "gesto" com a dor de um lamento, vendo-se obrigada a deixar, a abandonara contragosto. Pois, no fundo, no fundo, não é o que queria fazer. $\mathrm{O}$ decisivo no abandono da paciência é realizar o deixar sem a tristeza que ronda a tomada de ciência da consciência. Nesse ato final do pacientar até mesmo a consciência é abandonada, em detrimento da inocência de uma outra e nova consciência adquirida mediante a inocência da fé. Esse deixar que encontra contentamento na própria liberdade anímica - a "nudez da alma" - perfaz a simplicidade do gesto mais difícil. $\mathrm{Na}$ simplicidade essencial desse gesto paciente, locupletamo-nos apenas do nada, e "Perder o nada", já dizia Manoel de Barros, "é um empobrecimento"(BARROS,2013,p. 40). Esse nada que se abre do fundo da alma, como fagulha divina e propriamente humana, é o "infinitamente mais certo" (KIERKEGAARD, 2007, p. 15), apesar de ser nada. E aquilo que era coisa sólida e 
segura, o "mundo" desejado e tangível, tornar-se o mais duvidoso. $\mathrm{Na}$ paciência, o "mundo" almejado pela alma revela-se como ilusório.

A aquisição do "mundo" pela alma apresenta uma recíproca propriedade. Se a alma quer adquirir o "mundo", presume-se que ela possui a si mesma. Mas, se ela quer adquirir a si mesma, ela encontra-se sob a posse do "mundo" que precisa ser abandonado para então adquirir-se. Para adquirir a si mesma, ela precisa entregar o "mundo" que possui, e que, simultaneamente, a possui na propriedade da própria posse que tem dele: "O mundo só pode ser possuído de tal forma que me possua a mim" (KIERKEGAARD, 2007, p. 18). Com a atração e aderência ao "mundo", a alma contrai um desespero. A posse do mundo compõe, com a alma, uma recíproca possessão. A renúncia da alma possessa perfaz, portanto, uma dupla renúncia; pois querer a si mesma é, paradoxalmente, não apenas abandonar o mundo, mas abandonar-se. Pois na experiência do espírito, perder-se na paciência é encontrar-se.

Mais à frente, no discurso sobre a paciência, Kierkegaard chama de "imperfeito" esse mundo que reciprocamente possui a alma. Em contrapartida, chama de "perfeito" o modo de ser da alma adquirida na paciência (pp. 18-19). Esse "perfeito" perfaz a plenitude da liberdade humana, como índice da alma voltando-se sobre si mesma, movendo-se a si mesma, adquirindo-se. Na relação aderida ao "mundo" há um malogro na consumação dessa liberdade, porque a alma é movida por algo externo a ela: o "mundo". Com efeito, ela não desempenha o seu modo próprio de ser na liberdade e vive movida pelo eixo mundano que a possui. A não realização do movimento que a si mesmo move, desde si mesmo, é a im-perfeição da alma. Na ânsia da impaciência, a alma é movida a partir de um ponto externo, o "mundo".

O modo "imperfeito" como a alma possui a si mesma é o modo de ser possuída pelo "mundo", mas em um grau de possessão muito maior do que ela a si mesma possui. Em se tratando de um poder mais poderoso, o homem só possui o "imperfeito", o "mundo", sob dívida com o seu senhorio, o que se configura uma 
espécie de posse sem posse, como no caso, grosso modo, de uma "alienação fiduciária". Ou seja: o homem até possui o usufruto do mundo, mas a propriedade continua sendo da alteridade que possui a sua alma endividada. Mas a divina relação aberta na paciência há um paradoxo: o que atrai e contrai matrimônio com a alma não a distrai da paixão comprometida com um essencial celibato. Quando a relação da alma é estabelecida com o "perfeito", i.e., de modo perfeito, a alma não apenas possui e adquire a si mesma, mas aprofunda-se cada vez mais nessa perfeita aquisição(p. 19).Esse movimento de aprofundamento dá-se justamente quando a alma está livre de todas as coisas, movendo-se desde a relação solene que estabelece consiga própria. Ela não se move mais a partir de algo externo, mas desde a inteireza da interioridade, ou seja, somente a partir de si mesma, do desamparo da própria solidão, da vida que se é, que se lança através da diáfana relação consiga mesma e como Outro.

Quando ocorre o aprofundamento nisso que é o "perfeito", enquanto afundamento na liberdade, todo esse movimento de libertação perfaz a experiência de angústia. A angústia, como sendo a "realidade da liberdade como possibilidade para possibilidade"(KIERKEGAARD, 2013, p. 45), é o sentimento que sente a "diferença" (Forskjellig) entre aquilo que existencialmente se é e a dominação que o "mundo" exerce sobre a vida, tendendo a possuir e a desfigurar esse propriamente humano, à medida que a alma deseja possuí-lo. Aquilo que constitui o propriamente humano, a liberdade, encontra uma "resistência" que obstaculiza a passagem livre para a realização da possibilidade que se é. No homem, a angústia é quem empreende essa "resistência" vital estabelecida contra "os movimentos da vida do mundo" (KIERKEGAARD, 2007, p.19).

A questão dessa resistência entre o mundo e a alma não deve ser vista imediatamente a partir de uma incompatibilidade essencial, como se a alma para poder ser si mesma devesse manter uma distância asséptica do "mundo" impuro. Esse olhar não está atentando para uma questão decisiva que ocorre na paciência, 
pois à medida que se relaciona com o "mundo", a alma não perde, necessariamente, sua constitutiva liberdade. A alma ocupa-se com o mundo, no mundo, pelo mundo, mas jamais pode ser/ficar pré-ocupada nele/com ele. $\mathrm{Na}$ ocupação com o mundo, ela guarda a si mesma na pré-ocupação essencial do pacientar. A paciência é o que guarda a abertura livre desse pré- que se abre para desempenhar qualquer ocupação. Esse pré- é o âmbito que a paciência resguardada relação com "mundo", com as coisas, para permanecer na paciência. Dessa forma, o próprio "mundo" deixa de ser um "mundo" constituído, para ser a constituição contínua da possibilidade de ser a cada vez um novo mundo. Essa contínua possibilidade que é a alma, é a condição permanentemente livre do homem. Nada pode ocupar, obstaculizar essa passagem livre; nada pode cimentar a abertura dessa fenda. Se, na relação com o mundo, alma não pré-ocupar-se em manter essa livre passagem, à medida que se relaciona com o "mundo", ela pode ser, de súbito, totalmente ocupada por ele. O nome dessa ocupação acachapante que quase aniquila completamente a liberdade, é chamada por Vigilius Haufniensis de “angústia diante do bem”:o demoníaco (KIERKEGAARD 2013).

O "desassossego" (Uro) que a alma experiencia, como sinal da "diferença" que subsiste entre si e o "mundo", precisaria ser "esmagado" (overvinde) como condição para se obter e manter-se a "glória" do mundo.Mas, para aquele que quiser adquirir-se na paciência, é preciso "deixar" (lade) que a "diferença" que resiste se evidencie, tornando-se "nítida" (tydeligere). A força que suporta a "diferença", deixando que a resistência libere a vida para vir à luz, é a própria ocasião para se adquirir a alma na paciência. Diante desse crítico "desassossego" da alma, se houver o tentame de contornar (overvinde) ${ }^{14}$ isso que a aflige, haverá uma

\footnotetext{
14 “No primeiro instante, o homem está, assim, no ponto a que os homens mais tarde aspiram como sendo a glória. Está perdido na vida do mundo, possui o mundo, quer dizer, é possuído por ele. Mas, ao mesmo tempo, ele é diferente de todo o mundo e sente uma resistência que não acompanha os movimentos da vida do mundo. Se ele, então, quer possuir o mundo, deve esmagar este desassossego, até que novamente se desvaneça como as ondas na via do mundo - e, então, conquistou o mundo. Se, pelo contrário, quiser adquirir a sua alma, então tem de deixar que esta resistência se torne sempre e cada vez mais nítida e,
} 
paulatina perda de si na impaciência. E a impaciência, como avesso da paciência (a aquisição da alma), será a perda da alma, o "demoníaco". Por essa razão, afirma Riobaldo: "Deus é paciência. O contrário, é o diabo" (ROSA, 2006, p. 17).Quando o texto afirma que é preciso "deixar" (lade) que a "resistência se torne sempre e a cada vez mais nítida" (p. 19), esse "deixar" fala justamente da alma que, ao acolher pacientemente a "diferença", serena, deixando que a alma venha à luz, nascendo para si mesma, adquirindo a sua identidade na diferença. A relação com "mundo", na paciência, agrava essa tensão, porque a paciência não nos isola do mundano. Pacientar-se não é isolar-se.

Nós tendemos a compreender "mundo" como sendo alguma coisa física, objetiva, material, etc. da qual precisamos sistematicamente nos colocar em abstinência. Pensamos: o mundo deve estar lá e o eu da alma aqui. E a aquisição da alma seria justamente o despojamento disso ao modo de uma ermitania: "dar tudo ao pobre", "ir morar na floresta", etc. Seria então deixar o "mundo" o mesmo que ascese? Paciência não é ascetismo, apesar de ser a experiência de um contínuo exercício $^{15}$ de tornar-se a própria solidão. Um movimento ao modo da ascese, habitualmente conhecida, poderia ser configurado "como expressões da exterioridade" que Kierkegaard diz ser a condição do "pássaro rico"(p. 9). Este modo de ser "rico" não diz respeito exatamente ao rico no sentido pecuniário, mas sim àquele tipo que está soçobrado no "mundo", ou seja, no próprio desejo avaro, entregue a um desejo que cresce do desejo, como fome que aumenta, à medida que come, fome que cresce infinitamente da fome, de mais fome. E, por essa razão, mesmo que esteja apartado em alguma floresta, essa avareza ainda assim poderá acometê-lo, importuná-1o.

nisso, adquirir a sua alma. Pois a sua alma era precisamente esta diferença: era a infinitude da vida do mundo na diferença de si mesma (p. 19).

${ }^{15}$ Talvez, pensando desde o sentido propriamente grego, caiba se falar de ascese enquanto áskesis(“prática, “exercício”) e de sua relação com a paciência, pois na paciência se exercita a prática de um deixar. Mas, aqui, não há qualquer possibilidade de se pensar áskesis enquanto isolamento do "mundo". 
A riqueza mundana do "pássaro rico" não é capaz de extinguir sua pobreza mais originária. Por isso, vez ou outra, sente em si, de maneira lancinante, o desassossego da pobreza do nada constitutivo da alma, pesando-lhe como uma finitude que não quer para si, e, justamente porque rejeita, tenta contorná-la (overvinde). O "mundo" é o tudo que torna o "pássaro rico" para aliviá-lo da pobreza de seu nada anímico. Mas a paciência é um "pássaro pobre", pois ainda que tenha tudo, sabe que não tem nada, não é nada, e também não quer nada - nada além do nada. O "pássaro rico", por sua vez, quer perder esse nada, e, por essa razão, precisa ser rico: não pode perder tudo nem deixar nada; não pode abandonar o "mundo", i.e., o próprio desejo avaro e indômito de desejar. $\mathrm{O}$ alvoroço do pássaro rico que vem com expressões exteriores condiz com a agitação da avareza, tentando desfazer, pela posse do "mundo", o nada constitutivo da "nudez da alma". Mas, na paciência, a alma pode recobrar a riqueza desse nada constitutivo, ao deixar, ao abandonar o "mundo", i.e., ao abandonar aquilo que a possui como cobertura da "nudez da alma", e que, por isso, lhe prometia aliviar o peso do nada. A paciência é o exercício de sincronização da vida com um instante que nada mais almeja, pois sempre já se enriquecera com o nada constitutivo da alma nua. A paciência é o ânimo que suporta, que aguenta corajosamente o modo de ser dessa nudez. O "mundo" que a impaciência deseja é apenas a tentativa imperfeita e inglória de agasalhar o corpo desse desamparo.

O desamparo é a aquisição da alma em solidão, o que Johannes de silentio apontou como sendo a paixão da fé: "relação absoluta com o absoluto" (KIERKEGAARD, 2009, p. 114). Esse modo ab-soluto é o modo de solidão. A solidão paciente da fé não contrai qualquer dívida relativa a alguém: “...só quando quer adquirir a paciência, só então não se torna devedor de ninguém"(p. 24). Adquirir a alma na paciência é adquirir a própria paciência enquanto aquisição de solidão. Da paciência nasce o homem autêntico, o ab-soluto; pois authentikós é "o que 
faz por si mesmo", não é devedor de ninguém - a não ser do amor com o qual contrai o matrimônio de uma "dívida infinita" (KIERKEGAARD, 2005, p. 218).

\section{Considerações finais}

Afanados na corrida diária do desespero, olhamos, tateamos, esbarramos, como gestos que se agitam mobilizados pelo afã da temporalidade. Em tal sentido de tempo nos movemos, mas sem transcender o que já está dado enquanto "mundo" constituído e ambicionado. Assumimos esse modo de ser habitual porque já nos movemos habitados pela Legião do "mundo" que adoramos. Aderidos a esse "mundo", e com a pele já embrutecida, fazemos gestos que não veem, que não tocam, que não aproximam. São gestos que não geram e gestam qualquer vida. Mas, na paciência, a vida recobra seu fôlego inaugural, o viço de sua pele, e sente, sob a pulsão de um instante de eternidade, uma transcendência que volta a en-gravidar, a tornar grave, sério, os gestos de seus toques. A paciência desbrida o corpo embotado, para fazer res-sentir a linguagem que fala antes mesmo que qualquer palavra possa ser proferida. Por essa razão, Kierkegaard mostra que na paciência se adquire a alma, porque adquirir a alma é recobrar o sentir que afina a vida a um outro sentido de tempo, mais vital, mais originário: a arquivida. $N a$ paciência gestase a arquivida que a cada vez recria, com liberdade, uma nova arquitetura de mundo. É apenas do vazio da nudez da alma que pode rebentar extraordinariamente vida. 


\section{REFERÊNCIAS}

ANDRADE, Carlos Drummond. Corpo. Ed. $1^{\text {a }}$. São Paulo: Companhia das letras, 2015.

BARROS, Manoel. Livro sobre nada. São Paulo: LeYa, 2013.

KIERKEGAARD, Søren. Adquirir a alma na paciência, trads. N. Ferro; M. Jorge de Carvalho, Lisboa: Assirio \& Alvim, 2007.

ed.,São Paulo: Abril Cultural, 1979.

O Desespero humano, trad. Adolfo Casais Monteiro, $1^{\mathrm{a}}$ .O Conceito de angústia, trad. Álvaro Valls, Petrópolis:

Vozes, 2013.

Relógio D'água, 2009.

Temor e tremor, trad. Elisabete de Sousa, Lisboa:

MEIRELES, Cecília. Poesia completa, V I e II, Rio de Janeiro, Nova Fronteira, 2001.

NANCY, Jean Luc. Arquivida - do senciente e do sentido. Trads. Marcela Vieira, Maria Paula Gurgel Ribeiro. Ed. 1ª . São Paulo: Iluminuras, 2017.

NIETZSCHE, Friedrich. Assim falou Zaratustra - um livro para todos e para ninguém, trad. Paulo Cesar de Souza. São Paulo: Companhia das Letras, 2011.

PAZ, Octávio. O arco e a lira. Trad. Olga Savary. Rio de Janeiro: Editora Nova Fronteira, 1982.

PESSOA, Fernando. Obras completas - obra poética. V. único. Rio de Janeiro: Editora Nova Aguilar, 1986

Fronteira, 2016.

Obra poética. V. 2. $1^{\text {a }}$ ed. Rio de Janeiro: Editora Nova

ROSA, João Guimarães. Grande sertão: veredas. Rio de Janeiro: Nova Fronteira, 2006. 